Nate of Alasika

partment of Neturel Resources

DIVISION OF MINES AND MINERALS

\section{PROPERTY OF \\ LIBRARY \\ STATE OF ALASKA DIVISION OF \\ GEOLOGICAL SURVEY}

P. O. Box 1391

Juneau, Alaslora

\author{
MTNES AND PEIROLEUM BULLETIN \\ August, 1963 \\ MINING ACTIVITY
}

$\begin{array}{ll}\text { Vol. } & \mathrm{XI} \\ \text { No. } & 8\end{array}$

Northwestern: Word has been received from Nome that Walt Glavinovich and crew moved USSR\&M Company's No. 5 dredge onto a dry pad from the dredge pond. The Compeny's dredging operation at Nowe 18 now shut down for an indefinite perlod.

John Novak and Milton Morgan are working on their offshore prospecting permits in the Bluff area. B1ll Nunz 18 doing assessment work snd doesn't intend to mine this year.

The Lee brothers are active at their Solomon River Camp. Herb Bagstrom intends to dredge. Newmont MIning Carpany and the USSR\&M Company are actively prospecting beryllium claims in the Lost.RIver area.

Bear Creek Mining Company has two diamond drills going in tho Kobuk area. Several of Alaska's jade dealers were active in the Shungnak area collecting jade for their shops.

Doug Colp's dredge is operating on Klery Creek north of Kiana, and be bas conatructed an air strip nearby. Archie Ferguson is mining in the Candle area. Grant Neleon has one dredge running on the Inmechuk River.

Southeastern: Dick Denny, Assayer, reports that several prospector bave left for the bills. Nearly all of them are participating in the Prospectors Assistance Progrem.

The Kendrick Bay Mine is still actively producing uranium ore and carrylng on development work.

\title{
COAL NEWS
}

Wiley Rolinson, State Conl Mine Inspector, reports that the coal mines are busy with thelr new contracts. Cole McFarlend has been transferred by Joint Ventures, Inc., to Californta, and Hugh Matheson has been appolnted generel manager of the Even Jones Coel Kine in Cole's place.

\section{OIL NEWS}

Two permits to drill have been issued since the lest report. They are as Pollows:

Union Oil Co.--Kalk Arm State \#1. Surface location $1300^{\prime} \mathrm{N}$ and $1700^{\prime}$ g of sW corner, Section 1, TI4NR4W, SM. Subsurface location 1000' E of surface location. This directional hole is being drilled on uplands bordering the west side of Knik Arm north of Archorage and w1ll be bottomed on State owned submerged lands under Knik Am.

Gulf Oil Corporation--Sandy River Federal 价. Location 1991.4' S and 1543.5' W of NE corner, Section 10, 46S7OW, SM. This is Gulf Oll Corporation's firat drilling operation in Alaska. It lies on the Alaska Peninsula 20 miles northeast of Port Moller.

Drdlling Activity:

operator

ichfleld

-'an American

Pan Amer1can

Pen American

Shell

SoCel

Union
We11 Number

Wide Bay Unit

Cook Inlet \#I

Midale Ground Shoal \#2

Cook Inlet \#1A (Relief well)

Midōle Grouna shoel \#l

SRU 2l-16

Kenai Unit $43-9$
Stetus $7 / 26 / 63$

Drilling

Burning

Drilling

Dril] ing

Drilling

Driling

Testing 
Complet1ons:

Pan American

British Petroleum

Moose Creek \#1

WRU 俳3

PEA (7/26/63)

P\&A $(7 / 26 / 63)$

Production, Swanson Rivex Fleld, Hemlock Zone:

\begin{tabular}{|c|c|c|c|}
\hline & Producing Wells & $\therefore$ 011-Barrels & $\operatorname{Ces}$ (MCF) \\
\hline $\begin{array}{l}\text { June, } 1963 \\
\text { Cumulative to July 1, } 1963\end{array}$ & 54 & $\begin{array}{r}866,712 \\
22,638,092\end{array}$ & $\begin{array}{r}223,711 \\
4,540,466\end{array}$ \\
\hline
\end{tabular}

Production, Kenat Gas Field:

June, 1963

2

202,081

Cumulative, to July 1, 1963

$3,434,150$

Production, Sterling Gas Field:

June, 1963

Cumulative to July 2,1963

Production, Swanson River Gas Fleld, Kenal Zone:

June, 1963

6

Cumulat Ive to July 1, 1963

$-463,496$

$2,158,094$

Ges Injection, Swaneon RIver Field, Hemlock Zone:

June, 1963

Cumelative to July 1, 1963

Mr. Karl I.VonderAhe of Cooper Landing has been appolnted to the position of state Petroleum Englneer. Mr. VonderAbe replaces Konneth "Ty" Davison; wo reglened June 19. Be started his career with 21 years of varled engtheering positions with Richfield OII Corporstion. He spent Plve and a half years on the Arctle slope in the devalognent of Pet. \#4 by the Navy, and 4 years as Chief Petroleum Fagineer in Colombla, South America. He has been Bctive in Oregon and Alaske in recent years.

Mr. Richard I. Denny, Assayer, Ketchlkan District Office, has submitted his resignation to accept a position with the Eegle-Picher Compeny, Galene, IIlinols. D1ck had worked for them as a mining engineer before coming to work for the DMeM. Thts position is now open for application.

\section{NEW PUBLICATIONS}

\section{U. S. GEOLOGICAL SURVEY:}

Geology and Petrology of Two Stocks of Layered Cabbro in the Falrweather Range, Alaska, by I. L. Rosaman, 1963, Bulletin \#1121-F.

Geology of the Eastern Part of the Mount Fairweather Quadranglo, Glacler: Bay, Ajaghen, by D. L. Rossman, 1963, Bdllet in \#1121-K.

Reconnaissance Geology of Northern Baranof Island, Alaska, by H. C. Berg and D. W. Hinckley, 1963, Bulletin \#1141-0.

These bulletins are available over the counter at the Survey's Public Inquiries affice, in the Cordove Bullding at Anchorage, and by mall from the USGS at 520 IIIInolo Street,. Falrbanks. "They are available for reading at the various Survey DMM offlces. 


\section{U. S. BUREAU OF MTAES PRESS RETRASE}

The U. S. Bureau of Mines announced the Identification of phenacite, an oxide of berylyium In samples taken near the Kendrick Bay Uranium Mine. The area containing the berylitum Is; apparently nearly ell covered by existing mining claims.

\section{MANGANESE, A CLUE TO OTHER MEIATS}

The July 18sue of Minlag World megazine contains an interesting articfe by. D. F. Bevatt,$\ldots$ United States Geologdcel Survey. The gist of the two pege erticle is as follows:".

About 200 velns of five specific types have been explored in Soutbrestern U. S. and Northern Nexico. The flve types are: hypogene minganese oxide, berlte, fluorite, goldsilver, and bese rietal velns. Manganese minerels have been mined from three of these types of veins. Base and preclous metels have been mined from all five types. Vany samples of: near-iurface renganese ores show the presence of base and procioul metals. Many of the Ifve types appear to be of the seme metallogenetic epoch. Only a few of these veins have been inlned to depting greater than 100 feet. Prospecting in depth is warrented in seoldne:.. procious and base metal ores in many of these veing kowown to contain oulphides In the neer-surface manganese ores. A zonal pattern in plan can be shown--fram mangapese to base metal deposits-in several important mangenese mining alstricts. In Butte, Montana, the. same zonling in plan hes been found by exploration. S1milar zoning in depth is probalie In. other districts.

$$
\text { NOLICE TO MHNING CLATMARIS }
$$

Six more areas have been designated by the U. S."Forest service for the deterninetion of -urface rigbts on mining clatms under Public Lew 167 of July 23, 1955. These aje" in add-

:10n to many earlier arees within the Tongass and Chugach Nationel Forests, ell reported In earlfer DMGM bullet1ns. Holders of the clatms staked prior to the date of the Act have 150 days from the starting date of publication to flle verified statements if they wish to retaln exclusive surface rights to their claims. Flrat: publication will be August 7, 1963, in the Ketchlkan Dally News, and August 9, 1963, in tbo Wrangell Sentinel.

The o IX areas in generaI are: 1) W1lson Arm ares-all Iend surrounding W136on Arp, BaboWell Arm, the northern pert of Boca De Quadra, and iti Lower drainage pattern; 2 ) Princeso Bay area--includes a narrow strip of land extending from the headwaters of the streams entering Frincess Bay, southward elong the shoreline to include land along Farrow pasp; and all. of Rudyard Ioland; 3) Blue RIver area--a trlangular plece of land that includes both banks of the Blue River; both benks of the Unuk River to a polnt below Firat Canyor, ind entending upriver to the U.S.Cenadian boundary; 4) Cape Pole-Sh1pley Bay area--Includes oll Nat1anel. Forest land on the western most part of the kosclusko Island, Trout Creek drafnege, and: Mt. Francis, excluding those homesites within USS 2615, 2616, and 2617 at Capo Pole; 5) EI Capitan Passege area--a nerrow strlp of land along the east shore of Eli. Capitan passage on Prince of Wales IQland; 6) Lava Creek-Exchange Island area--a narrow east-west strip of land that extends Inland from Exchange Island to Include the head of Lave Creok and the south drainage of Salmon Bay Lake.

\section{ALASKAN ATME CONTERENCE}

Berl H. Belgtilne, Dean of the College of Earth Sclence and Mineral Industry, Univeristty of Alaska, Inform us that an ATME conference has been schoduled for March 18 to 20, 1964, at College, Aleska. The theme of the conference is planned to be "Recent Develogments" in the Mineral Industry". Speekrers are now being sought. Anyone with ouggest tons as to wossible speakers and subjects should contact Dean Belstitne at the above address. 
A large copper deposit about 70 mlles NE of Wrangell at the junction of the Stikine and Scud Rivers is presently being explored. Kennecott Copper Company, :Hudson Bay Mining and Smelting Co. Ltd., and Consolidated Mining and Smelting Co. Ltd, have formed Stikine Copper Ltd. for exploration of the deposit. It is reported that they presently have 200 claims and are working 10 diemond drills.

Even though this deposit is across the border, Alask should benefit since the neareat port of entry is Wrangell.

Details of tonniage and grade are not known at this date.

\section{GOLD. BIIL HEARTINGS}

The American Mintig Congress reports that Federal Treasury and Comerce officials as well as spokesmed from the domest1c gold manufacturing industry spoke against both, b1lls before the Senate Interior Subcomittee on Minerels; Materlals; and Fuels.. Bills S.100.and S.1273 would result in a study of the gold mining industry and allow the miner to sell. gold for domestic consumption at prices over the present $\$ 35$ por ounce.price. The price of domestic gold would be derived as a result of the study and determined by the secretary of the Interlor. The price could not exceed \$105 per ounce.

Spokesmen from the mining Industry, several westem congressmen, and the senators from Alsoke teetifled in fevor of the bills.

Treasury and Commerce officials opposed the bills on the grounds that they createia: twoprice gold system and weaken the value of the dollar. However, Comerce officials thought assistance to depressed gold areas and retraining of personnel could be effected through the Area Redevelopment Administration."

E. AND M. J. MELAI MARKEI PRICES

Juily 29, 1963

Copper, per $1 \mathrm{~b}$. Leed; per. Ib. Zinc, per 1b. Tin, per ib. Nickel, per 10. Platinum, per oz. Mercury, per flsisk Antfimony ore, per unit Beryllium ore, per unit Chrome ore, per lang ton Molybodenum conc; per 16. Títanium ore; periton Tuagsten ore, per unit Silver, New York, per oz. SIlver, U. S. Treasury, per oz.

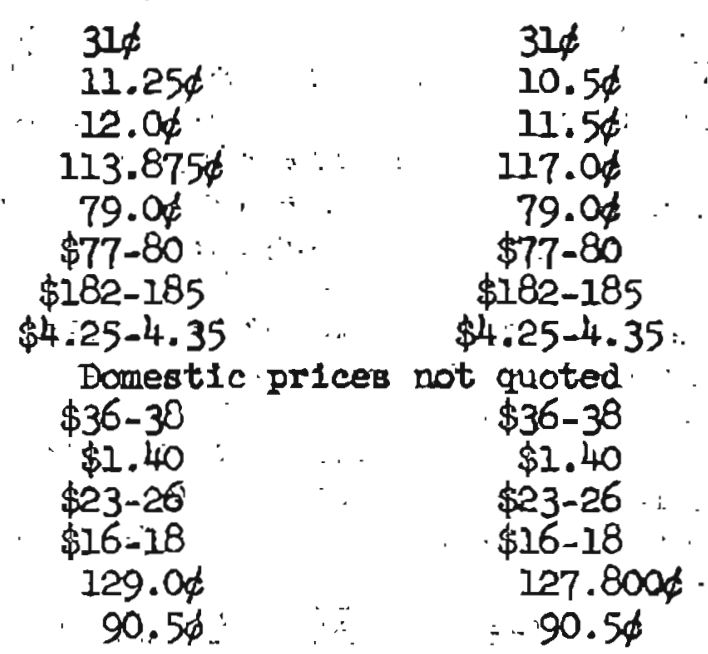

Month ago

Year ago

- 374 11.04 11.54 239.04 74.04 $\$ 80-85$ $\$ 200-203$ $\$ 4.35-4.50$ $\$ 46-48$ $\$ 36-38$ $\$ 1.40$ $\$ 23-26$ $\$ 22=24$ $91.4 \phi$ 90.54 